\title{
A vibrational spectroscopic study of a hydrated hydroxy-phosphate mineral fluellite, $\mathrm{Al}_{2}\left(\mathrm{PO}_{4}\right) \mathrm{F}_{2}(\mathrm{OH}) \cdot 7 \mathrm{H}_{2} \mathrm{O}$
}

\author{
Jiří Čejka ${ }^{\mathrm{a}, \mathrm{b}}$, Jiří Sejkora ${ }^{\mathrm{a}}$, Ivo Macek ${ }^{\mathrm{a}}$, Ray L. Frost ${ }^{\mathrm{b}, *}$, Andrés López $^{\mathrm{b}}$, Ricardo Scholz ${ }^{\mathrm{c}}$, Yunfei Xi ${ }^{\mathrm{b}}$ \\ ${ }^{a}$ Department of Mineralogy and Petrology, National Museum, Cirkusová 1740, CZ-193 00 Praha 9, Czech Republic \\ ${ }^{\mathrm{b}}$ School of Chemistry, Physics and Mechanical Engineering, Science and Engineering Faculty, Queensland University of Technology, GPO Box 2434, Brisbane, Queensland \\ 4001, Australia

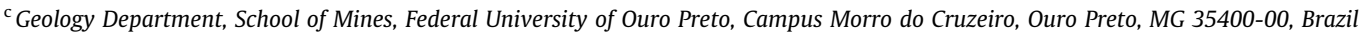

\section{H I G H L I G H T S}

-We have studied Raman and infrared spectra of two well-defined fluellite samples.

- From the Krásno near Horní Slavkov (Czech Republic) and Kapunda, South Australia (Australia).

- Observed bands were assigned to the stretching and bending vibrations of phosphate tetrahedra.

- Approximate $\mathrm{O}-\mathrm{H} \ldots \mathrm{O}$ hydrogen bond lengths were inferred.

\section{A R T I C L E I N F O}

Article history:

Received 17 November 2013

Accepted 31 January 2014

Available online 7 February 2014

\section{Keywords:}

Fluellite

Phosphate

Hydroxyl ions

Raman spectroscopy

Infrared spectroscopy
G R A P H I C A L A B S T R A C T

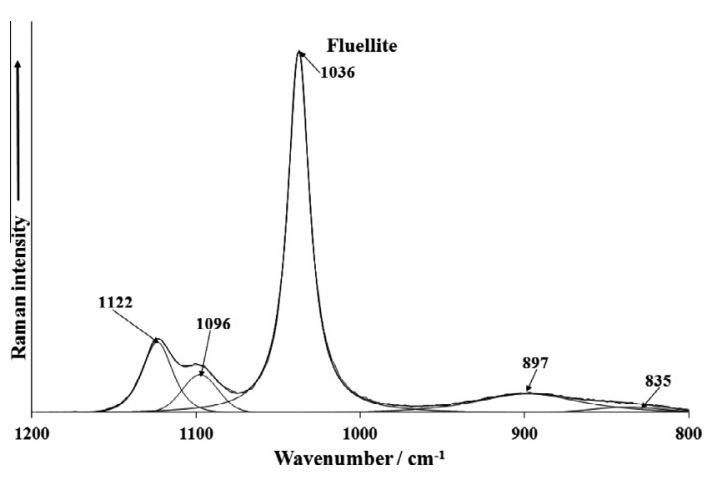

\section{A B S T R A C T}

Raman and infrared spectra of two well-defined fluellite samples, $\mathrm{Al}_{2}\left(\mathrm{PO}_{4}\right) \mathrm{F}_{2}(\mathrm{OH}) \cdot 7 \mathrm{H}_{2} \mathrm{O}$, from the Krásno near Horní Slavkov (Czech Republic) and Kapunda, South Australia (Australia) were studied and tentatively interpreted. Observed bands were assigned to the stretching and bending vibrations of phosphate tetrahedra, aluminum oxide/hydroxide/fluoride octahedra, water molecules and hydroxyl ions. Approximate $\mathrm{O}-\mathrm{H} \cdots \mathrm{O}$ hydrogen bond lengths were inferred from the Raman and infrared spectra.

(c) 2014 Elsevier B.V. All rights reserved.

\section{Introduction}

Fluellite $\mathrm{Al}_{2}\left(\mathrm{PO}_{4}\right) \mathrm{F}_{2}(\mathrm{OH}) \cdot 7 \mathrm{H}_{2} \mathrm{O}$ is very rare, late hydrothermal or supergene mineral formed by alteration of earlier phosphates minerals. It may be found as a colorless to purple-black crystals [1] but usually forms a colorless to white and yellow crystals or powder aggregates in association with fluorapatite, wavellite, cacoxenite,

\footnotetext{
* Corresponding author. Tel.: +61 73138 2407; fax: +61 731381804 .

E-mail address: r.frost@qut.edu.au (R.L. Frost).
}

variscite, strengite, minyulite etc. The size of the crystals is several $\mathrm{mm}$ rare up to $1 \mathrm{~cm} \mathrm{[2].} \mathrm{It} \mathrm{occurs} \mathrm{in} \mathrm{several} \mathrm{types} \mathrm{of} \mathrm{geological}$ environments, for example in complex granitic pegmatites [3,4], phosphatic marbles [5], in lateritic conglomerate and phosphatic sedimentary rocks [6-8] and at ore deposits [1,9-11].

Fluellite was described as a new mineral in 1824 by Lévy [12] without any quantitative chemical tests only with presence of aluminum and fluorine. Further chemical data were presented in 1882 by Groth [13] and proposed the formula $\mathrm{AlF}_{8} \cdot \mathrm{H}_{2} \mathrm{O}$. In 1920 Laubmann and Steinmetz [14] described mineral kreuzbergite from 
Oberpfalz, Bavaria as an aluminum phosphate. These two minerals with similar compositions existed till 1940 when Scholz and Strunz [15] carried out qualitative chemical analyses on kreuzbergite and concluded that it has the same composition as fluellite. The name kreuzbergite was discredited and only fluellite remained.

The mineral fluellite has orthorhombic symmetry with space group Fddd. Its crystal structure was solved by Guy et al. [16,17] and consists of octahedrally $[\mathrm{Al}-\mathrm{O}]$ and tetrahedrally $\left[\mathrm{PO}_{4}\right]$ coordinated cations in open framework arrangement within which there are distinct channels containing hydrogen-bonded water molecules. The aluminum atoms are situated at centers of symmetry and are bonded octahedrally to two centro-symmetric pairs of oxygen atoms and one pair of fluorine ions. Raman spectrum of fluellite from Gold Quarry mine, Maggie Creek District, Eureka County, Nevada (USA) was published in the RRUFF's data base (fluellite R070473) without any resolution of band wavenumbers and assignment.

The aim of this paper is to report the Raman spectra of welldefined natural hydrated phosphate minerals, fluellite from two different occurrences, and to relate the spectra to this molecular and the crystal structure. The paper follows the systematic research of the large group of oxyanion containing minerals [18-21], and especially their molecular structure using IR and Raman spectroscopy [22-25].

\section{Experimental}

\section{Minerals}

The studied samples of the mineral fluellite originated from two different occurrences: greisen Sn-W deposit Krásno near Horní Slavkov [2], western Bohemia, Czech Republic (labelled as CZ) and phosphate deposit Kapunda [26], Mt. Lofty Ranges, South Australia, Australia (labelled as AU). At both occurrences, fluellite forms very brittle, water-clear translucent dipyramidal crystals up to $1 \mathrm{~cm}(\mathrm{CZ})$ or only $1 \mathrm{~mm}$ in size (AU).

Carefully hand-picked samples were used for X-ray powder diffraction experiments. To minimize the complicated shape of background, the samples studied were placed on a flat low-background silicon wafer. Powder XRD measurements were carried out with $\mathrm{Cu}$ $\mathrm{K} \alpha$ radiation at a HZG4/Arem diffractometer $(50 \mathrm{kV}, 40 \mathrm{~mA})$ in the range $5-70^{\circ} 2 \theta$ in the step-scan mode $0.02^{\circ} / 5 \mathrm{~s}(\mathrm{CZ})$ and at a Bruker D8 Advance diffractometer $(40 \mathrm{kV}, 40 \mathrm{~mA})$ in the range $5-70^{\circ} 2 \theta$ in the step-scan mode $0.01^{\circ} / 8 \mathrm{~s}(\mathrm{AU})$. The position and intensities of reflections were calculated using the Pearson VII profile shape function in the ZDS program package [27]. The measured patterns were indexed using theoretical pattern calculated from the crystalstructure data of fluellite $[16,17]$. The unit-cell parameters refined from measured powder XRD using the program of Burnham [28] are compared with published data in Table 1.

The fluellite sample (CZ) was quantitatively analyzed by Cameca SX 100 electron microprobe system in wavelength dispersion mode for chemical composition. Studied sample was mounted into the epoxide resin and polished. The polished surface was coated with carbon layer $250 \AA$. An acceleration voltage of $15 \mathrm{kV}$, a specimen current of $10 \mathrm{nA}$, and a beam diameter of $5 \mu \mathrm{m}$ were used. Well-defined natural and synthetic compounds were used as

Table 1

Unit-cell parameters of fluellite.

\begin{tabular}{lllll}
\hline & $a[\AA]$ & $b[\AA]$ & $c[\AA]$ & $V\left[\AA^{3}\right]$ \\
\hline Krásno (CZ) & $8.558(1)$ & $11.237(1)$ & $21.179(2)$ & $2043.5(3)$ \\
Kapunda (AU) & $8.5703(5)$ & $11.2454(8)$ & $21.175(1)$ & $2040.8(1)$ \\
Cornwall [16] & $8.546(8)$ & $11.222(5)$ & $21.158(5)$ & 2029.12 \\
\hline
\end{tabular}

standards. The raw intensities were converted to the concentrations using automatic PAP matrix correction software package. The calculation of theoretical content of $\mathrm{H}_{2} \mathrm{O}$ corresponding to ideal formula provided the totals near $120 \mathrm{wt} . \%$ (Table 2); it indicates a strong dehydratation, corresponding to loss of two $\mathrm{H}_{2} \mathrm{O}$ molecules during sample coating in vacuum and analysis. This loss is indicated by irregular fracturing of the analyzes samples [2]. On the basis of $14(\mathrm{O}, \mathrm{OH}, \mathrm{F})$, empirical formula of fluellite from Krásno may be expressed as $\mathrm{Al}_{1.98}\left(\mathrm{PO}_{4}\right)_{1.07} \mathrm{~F}_{1.99}(\mathrm{OH})_{0.75} \cdot 7 \mathrm{H}_{2} \mathrm{O}$. Chemical composition of Kapunda fluellite (AU) was check by ED spectrum at the same EMPA, obtained ED spectra for both samples (CZ,AU) are practically identical, only very minor Fe content was found at AU sample.

\section{Raman and infrared spectroscopy}

Fragments of single crystals of fluellite were placed on a polished metal surface on the stage of an Olympus BHSM microscope, which is equipped with $10 \times, 20 \times$, and $50 \times$ objectives. The microscope is part of a Renishaw 1000 Raman microscope system, which also includes a monochromator, a filter system and a CCD detector (1024 pixels). The Raman spectra were excited by a Spectra-Physics model 127 He-Ne laser producing highly polarised light at $633 \mathrm{~nm}$ and collected at a nominal resolution of $2 \mathrm{~cm}^{-1}$ and a precision of $\pm 1 \mathrm{~cm}^{-1}$ in the range between 200 and $4000 \mathrm{~cm}^{-1}$. Repeated acquisition on the crystals using the highest magnification $(50 \times)$ were accumulated to improve the signal to noise ratio in the spectra. Spectra were calibrated using the $520.5 \mathrm{~cm}^{-1}$ line of a silicon wafer. Previous studies by the authors provide more details of the experimental technique. Alignment of all crystals in a similar orientation has been attempted and achieved. However, differences in intensity may be observed due to minor differences in the crystal orientation.

Infrared spectrum of fluellite sample from Kapunda was recorded by microdiffuse reflectance method (DRIFTS) on a Nicolet Magna 760 FTIR spectrometer (range $4000-600 \mathrm{~cm}^{-1}$, resolution $4 \mathrm{~cm}^{-1}, 128$ scans, 2 level zero-filtering, Happ-Genzel apodization), equipped with Spectra Tech InspectIR micro FTIR accessory. Sample of amount less than $0.050 \mathrm{mg}$ was mixed without using pressure with $\mathrm{KBr}$. Samples were immediately recorded together with the same $\mathrm{KBr}$ as a reference.

Spectral manipulation such as baseline correction/adjustment and smoothing were performed using the Spectracalc software package GRAMS (Galactic Industries Corporation, NH, USA). Band component analysis was undertaken using the Jandel 'Peakfit' software package that enabled the type of fitting function to be selected and allows specific parameters to be fixed or varied accordingly. Band fitting was done using a Lorentzian-Gaussian cross-product function with the minimum number of component bands used for the fitting process. The Gaussian-Lorentzian ratio was maintained at values greater than 0.7 and fitting was

Table 2

Chemical composition of fluellite from Krásno (CZ).

\begin{tabular}{lcrrrrr}
\hline wt.\% & Mean 1-4 & \multicolumn{1}{l}{ 1 } & \multicolumn{1}{l}{3} & \multicolumn{1}{l}{4} & Ideal $^{\text {b }}$ \\
\hline $\mathrm{Al}_{2} \mathrm{O}_{3}$ & 36.40 & 36.98 & 36.32 & 36.23 & 36.06 & 30.89 \\
$\mathrm{P}_{2} \mathrm{O}_{5}$ & 27.29 & 27.10 & 27.39 & 26.93 & 27.74 & 21.51 \\
$\mathrm{~F}$ & 13.65 & 13.54 & 13.37 & 13.96 & 13.75 & 11.51 \\
$\mathrm{H}_{2} \mathrm{O}^{\mathrm{a}}$ & 47.95 & 48.95 & 47.94 & 47.58 & 47.30 & 40.95 \\
$-\mathrm{F}=\mathrm{O}$ & 5.75 & 5.70 & 5.63 & 5.88 & 5.79 & 4.86 \\
total & 119.54 & 120.87 & 119.38 & 118.82 & 119.06 & 100.00 \\
\hline
\end{tabular}

Additional elements ( $\mathrm{Na}, \mathrm{K}, \mathrm{Mn}, \mathrm{Sr}, \mathrm{Ba}, \mathrm{Ca}, \mathrm{Cu}, \mathrm{Zn}, \mathrm{Fe}, \mathrm{Bi}, \mathrm{Si}, \mathrm{As}, \mathrm{S}$ and $\mathrm{Cl}$ ) were analyzed; the analysis confirmed their absence or contents below detection limits (ca 0.01-0.05 wt.\%).

a $\mathrm{H}_{2} \mathrm{O}$ content was calculated on the basis of ideal composition.

b Ideal composition calculated from formula $\mathrm{Al}_{2}\left(\mathrm{PO}_{4}\right) \mathrm{F}_{2}(\mathrm{OH}) \cdot 7 \mathrm{H}_{2} \mathrm{O}$. 
undertaken until reproducible results were obtained with squared correlations of $r^{2}$ greater than 0.995 .

\section{Results and discussion}

\section{Crystal symmetry and vibrational spectra of fluellite}

Fluellite, $\mathrm{Al}_{2} \mathrm{PO}_{4} \mathrm{~F}_{2}(\mathrm{OH}) \cdot 7 \mathrm{H}_{2} \mathrm{O}$, is orthorhombic, space group Fddd $-D_{2 h}^{24}, Z=8$. The structure consists of $\mathrm{AlF}_{2} \mathrm{O}_{4} \cdot \mathrm{H}_{3.5}$ octahedra linked through $\left(\mathrm{PO}_{4}\right)$ tetrahedra forming channels which contain the remaining water molecules. The water molecules and hydroxyl ions are hydrogen bonded. Two oxygen atoms in the $\mathrm{Al}^{3+}$ octahedra are shared with the $\left(\mathrm{PO}_{4}\right)$ tetrahedra. The other two are statistically one quater that of a hydroxyl ion and three quaters that of a water molecule [16,17]. According to Nakamoto [29], octahedral units $\mathrm{XY}_{6}$ exhibit six normal vibrations $v_{1}\left(A_{1 \mathrm{~g}}\right)$ and $v_{2}\left(E_{\mathrm{g}}\right)$ stretching and $v_{5}\left(F_{2 g}\right)$ bending vibrations are Raman active, while only $v_{3}$ $\left(F_{1 \mathrm{u}}\right)$ stretching and $v_{4}\left(F_{1 \mathrm{u}}\right)$ bending vibrations are infrared active. Symmetry lowering in the case of $\mathrm{XY}_{4} \mathrm{Z}_{2}$ may cause RA and IR activation of corresponding vibrations and also splitting of degenerate vibrations. Free $\left(\mathrm{PO}_{4}\right)^{3-}$ anion exhibits tetrahedral $T_{\mathrm{d}}$ symmetry. In the case of a free ion of $T_{\mathrm{d}}$ symmetry, there are 9 normal vibrations characterized by four fundamental distinguishable modes of vibrations: $v_{1}\left(A_{1}\right)$ symmetric stretching vibration, Raman active, $v_{2}(\delta)$ $(E)$ doubly degenerate bending vibration, Raman active, $v_{3}\left(F_{2}\right)$ triply degenerate antisymmetric stretching vibration, Raman and infrared active, $v_{4}(\delta)\left(F_{2}\right)$ triply degenerate bending vibration, Raman and infrared active. $T_{\mathrm{d}}$ symmetry lowering may cause IR activation of the $v_{1}$ and $v_{2}$ vibrations and splitting of the doubly degenerate $v_{2}$ and triply degenerate $v_{3}$ and $v_{4}$ vibrations. [29,30]. An overlap of stretching and bending vibrations of $\mathrm{AlO}(\mathrm{OH}) \mathrm{F}_{2}$ octahedra with stretching and especially with bending vibrations of $\left(\mathrm{PO}_{4}\right)^{3-}$ tetrahedra vibrations are supposed. Two fluellite samples were investigated, one sample from the Krásno, Czech Republic (CZ) and one from Kapunda, Australia (AU). RRUFF Raman spectrum of fluellite (specimen R070473 - Gold Quarry mine, Maggie Creek District, Eureka County, Nevada, USA) $\left(\mathrm{cm}^{-1}\right)$ : 1120, 1096, 1038, 910, 651, 585, 524, 462, 406, 313, 276, 211, 173 (Fig. S1). As usually, no interpretation of this spectrum was presented. Tentative assignment and interpretation of the Raman and infrared spectra of fluellite (Table 3 ) is realized with special regard to [29-33].

\section{Raman and infrared spectroscopy}

The Raman spectra of fluellite samples in the $100-4000 \mathrm{~cm}^{-1}$ spectral range are illustrated in Figs. 1a and 1b. These spectra show the position of the Raman bands and their relative intensities. It is obvious that there are large parts of the spectrum where little or no intensity is observed. Therefore, the spectrum is subdivided into sections according to the type of vibration is being investigated. In this way the precise position of the bands can be detailed. The infrared spectrum of fluellite (AU) in the $500-4000 \mathrm{~cm}^{-1}$ spectral range is shown in Fig. 1c. As for the Raman spectrum, the infrared spectrum is subdivided into sections depending upon the type of vibration being examined. The complete infrared spectrum displays the position of the infrared bands and their relative intensity.

Raman and infrared region of $v \mathrm{OH}$ stretching vibrations is presented in Figs. 2a-2c. Raman band at $3667 \mathrm{~cm}^{-1}$ (CZ) and infrared bands 3629 and $3559 \mathrm{~cm}^{-1}$ (AU) are assigned to the $v \mathrm{OH}$ stretching vibrations of weakly hydrogen bonded hydroxyls, $(\mathrm{OH})^{-}$. Raman bands at 3396,3314 and $3124 \mathrm{~cm}^{-1}$ (CZ) and 3411,3356 , 3222 and $3113 \mathrm{~cm}^{-1}$ (AU) and infrared bands at 3441, 3221 and $3047 \mathrm{~cm}^{-1}(\mathrm{AU})$ are attributed to the $v \mathrm{OH}$ stretching vibrations of hydrogen bonded, structurally (symmetrically) distinct water
Table 3

Tentative assignment of fluellite spectra.

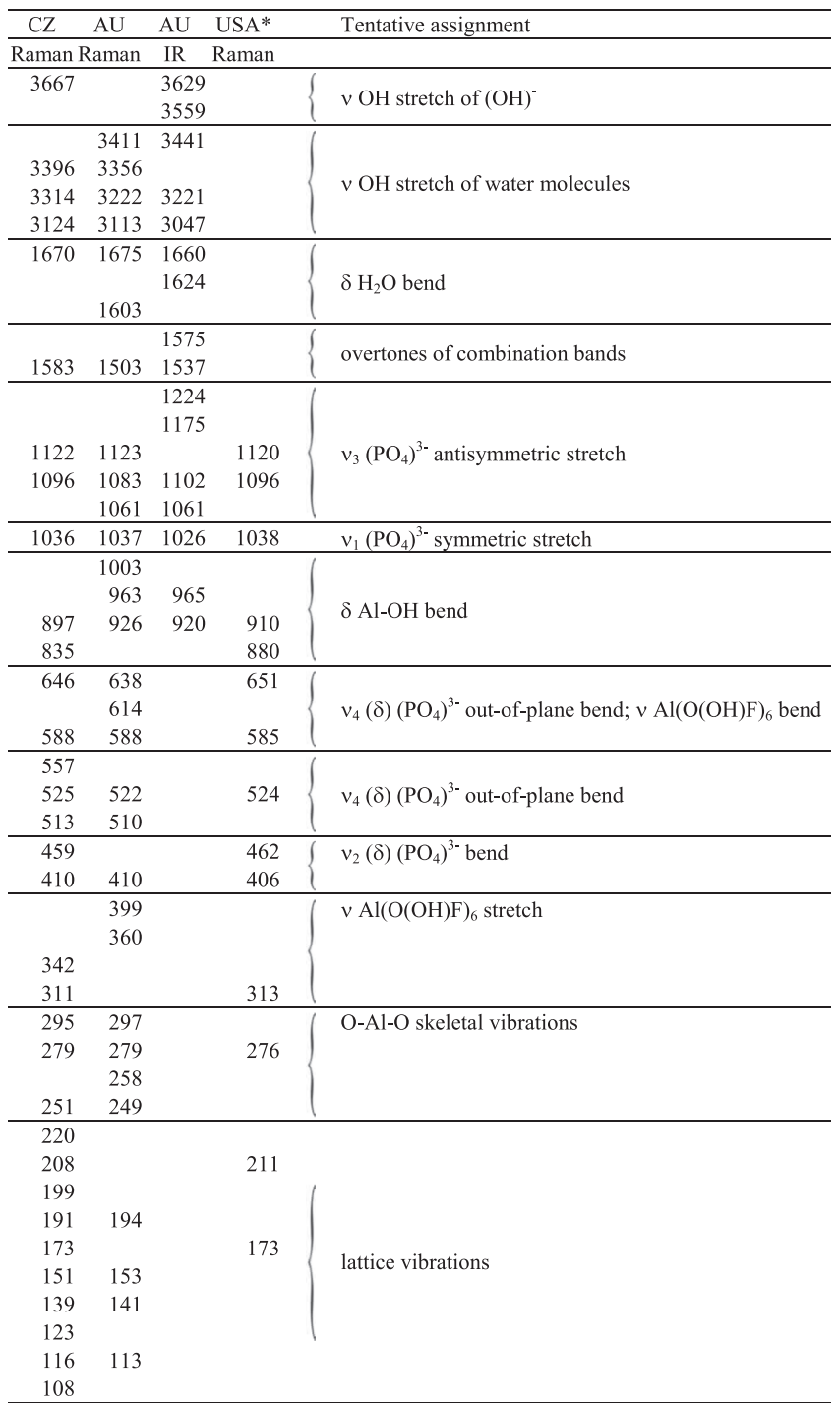

a USA RRUFF spectrum (R070473) of fluellite from Gold Quarry mine, Maggie Creek District, Eureka County, Nevada (USA).

molecules. Hydrogen bond lengths, O-H. . O, vary approximately in the range from $\sim 3.2$ to $\sim 2.67 \AA$ [34].

Raman bands at $1670 \mathrm{~cm}^{-1}$ (CZ) and 1675 and $1603 \mathrm{~cm}^{-1}$ (AU) and infrared bands at 1660 and $1624 \mathrm{~cm}^{-1}$ (AU) (Figs. 3a-3c) are connected with $v_{2}(\delta)$ bending vibrations of structurally nonequivalent water molecules. Raman bands at $1583 \mathrm{~cm}^{-1}$ (CZ) and $1503 \mathrm{~cm}^{-1}$ (AU) and infrared bands at $1575 \mathrm{~cm}^{-1}$ and $1537 \mathrm{~cm}^{-1}$ (AU) may probably be assigned to overtones or combination bands.

The Raman spectra of fluellite in the $800(900)-1200 \mathrm{~cm}^{-1}$ spectral range is reported in Figs. $4 \mathrm{a}$ and $4 \mathrm{~b}$. The Raman spectra are dominated an intense band at $1036 \mathrm{~cm}^{-1}(\mathrm{CZ})$ and $1037 \mathrm{~cm}^{-1}$ (AU) and the infrared spectrum (Fig. 4c) an weak band at $1026 \mathrm{~cm}^{-1}$ (AU) assigned to the $v_{1} \mathrm{PO}_{4}^{3-}$ symmetric stretching vibration. The Raman spectrum reported in this paper is in harmony with the spectrum provided in the RRUFF data base. The RRUFF spectrum shows an intense sharp band at $1038 \mathrm{~cm}^{-1}$. The Raman spectra (Figs. 4a and 4b) show resolved component bands at 1122 and $1096 \mathrm{~cm}^{-1}$ (CZ) and 1123, 1083 and $1061 \mathrm{~cm}^{-1}$ (AU) together with the infrared spectrum (AU) those at 1224, 1175, 


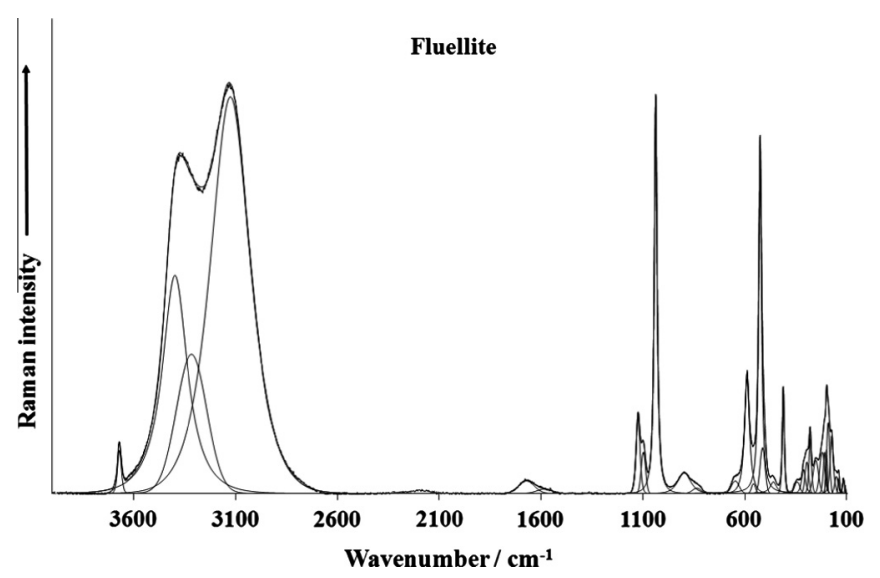

Fig. 1a. Raman spectrum of fluellite sample $C Z$ over the $100-4000 \mathrm{~cm}^{-1}$ spectral range.

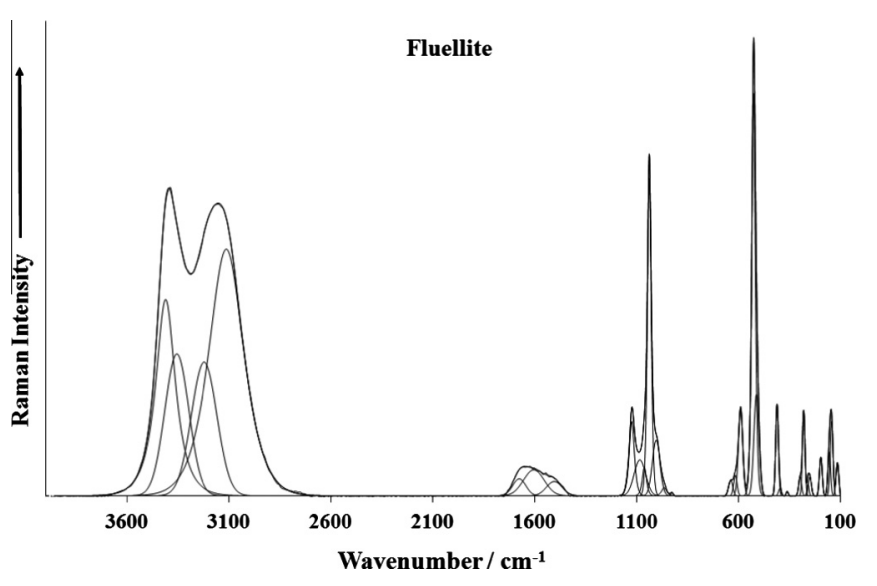

Fig. 1b. Raman spectrum of fluellite sample AU over the $100-4000 \mathrm{~cm}^{-1}$ spectral range.

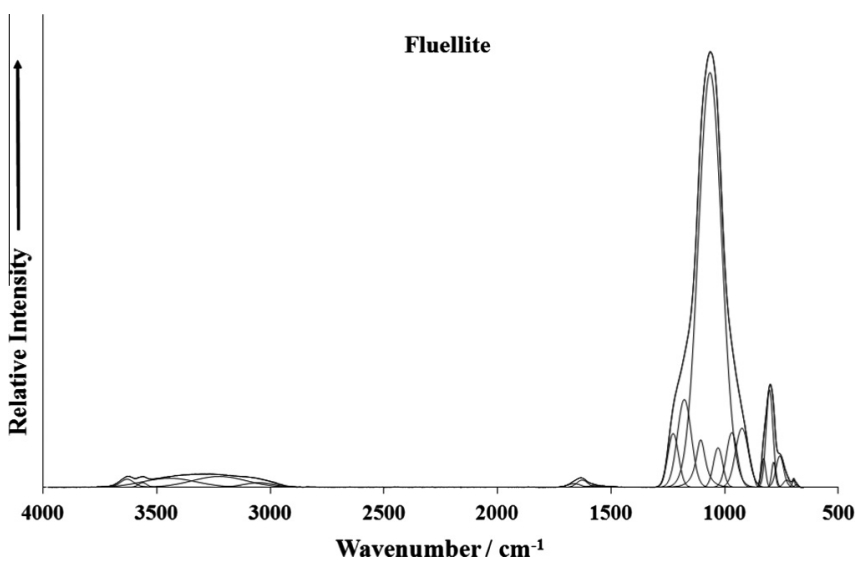

Fig. 1c. Infrared spectra of fluellite $A U$ over the $500-4000 \mathrm{~cm}^{-1}$ spectral range.

1102 and a strong band at $1061 \mathrm{~cm}^{-1}$. RRUFF Raman spectrum exhibits bands at 1120 and $1096 \mathrm{~cm}^{-1}$. All these bands are assigned to the $v_{3} \mathrm{PO}_{4}^{3-}$ antisymmetric stretching vibrations. There is also a weak Raman band at $1003 \mathrm{~cm}^{-1}$ (AU), which may probably be a shoulder to the very intensive band of the $v_{1}\left(\mathrm{PO}_{4}\right)^{3-}$ vibration or the $\delta \mathrm{Al}-\mathrm{OH}$ bending vibration. In the Raman spectrum of fluellite (AU) two low intensity component bands are observed at 963

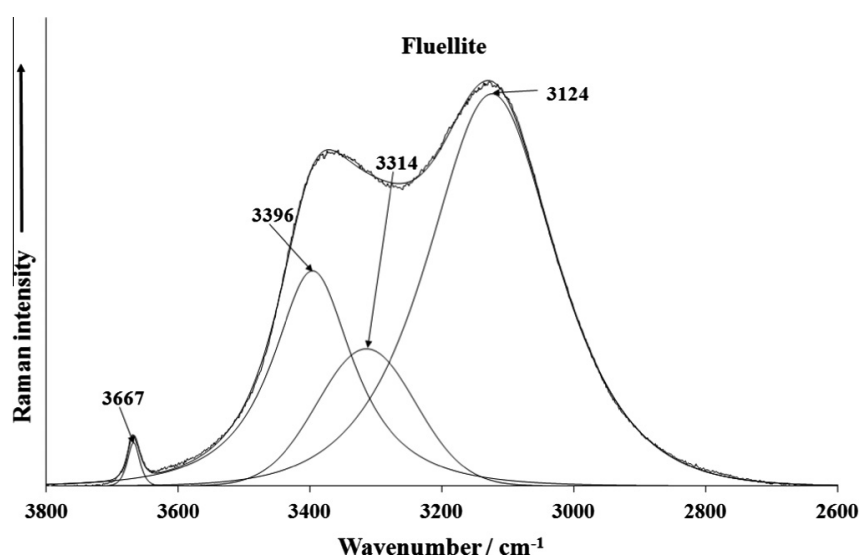

Fig. 2a. Raman spectrum of fluellite $C Z$ over the $2600-3800 \mathrm{~cm}^{-1}$ spectral range.

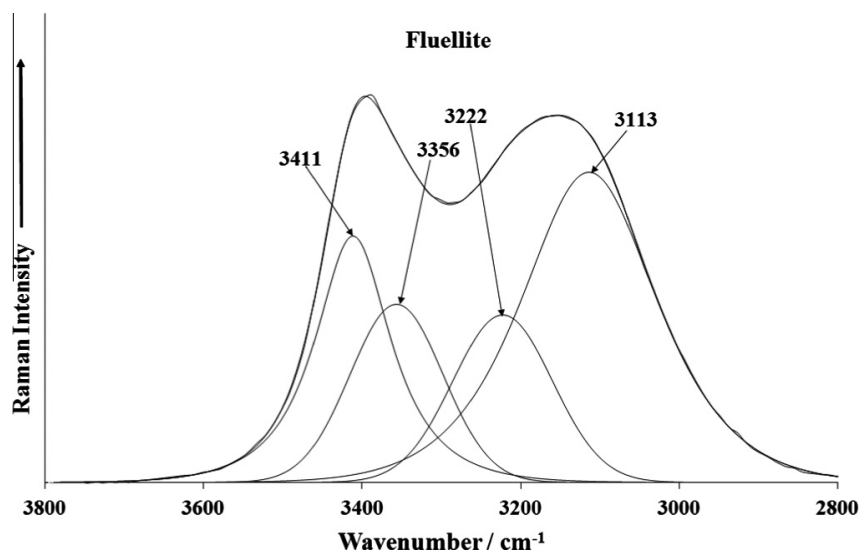

Fig. 2b. Raman spectrum of fluellite AU over the $2600-3800 \mathrm{~cm}^{-1}$ spectral range.

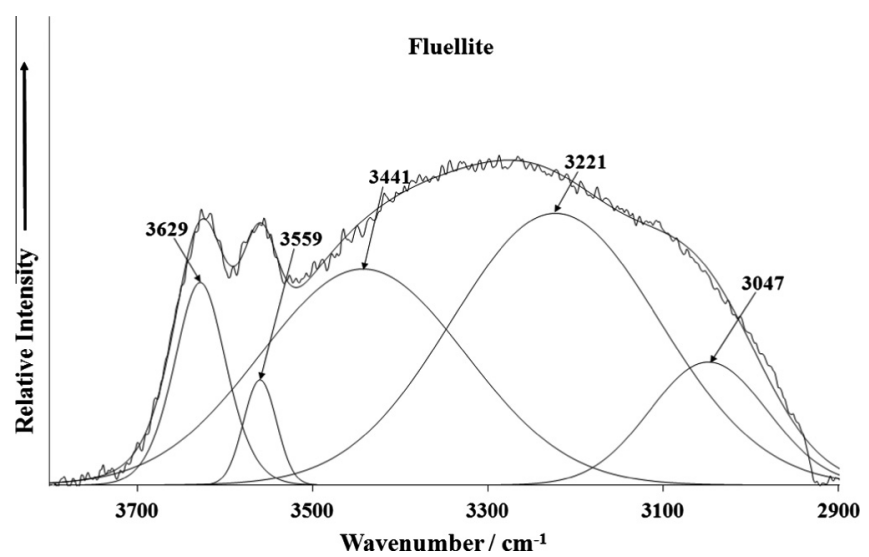

Fig. 2c. Infrared spectrum of fluellite AU over the $2900-3800 \mathrm{~cm}^{-1}$ range.

and $926 \mathrm{~cm}^{-1}$, which are related to the infrared bands (AU) at 965 and $920 \mathrm{~cm}^{-1}$. These bands together with the Raman bands (CZ) at 897 and $835 \mathrm{~cm}^{-1}$ may be attributed to the $\mathrm{Al}-\mathrm{OH}$ bending modes or to libration modes of water molecules. Normally the intensity of hydroxyl deformation modes are of a quite low intensity in the Raman spectrum but may show significantly greater intensity in the infrared spectrum. In the RRUFF Raman spectrum two broadish weak bands were observed at around 880 and $910 \mathrm{~cm}^{-1}$. It is suggested that these two bands may be due to hydroxyl deformation modes of the $\mathrm{AlOH}$ units. However, weak 


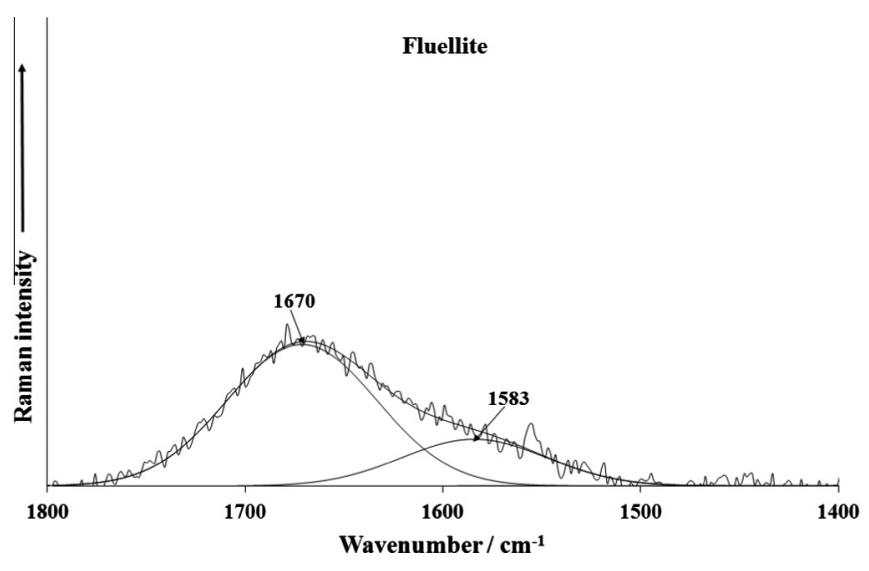

Fig. 3a. Raman spectrum of fluellite $C Z$ over the $1400-1800 \mathrm{~cm}^{-1}$ spectral range.

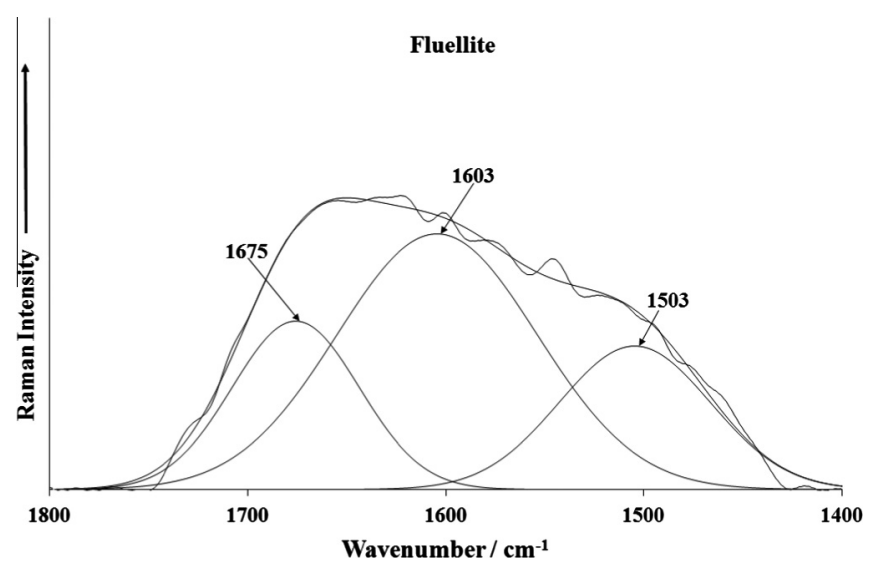

Fig. 3b. Raman spectrum of fluellite AU over the $1400-1800 \mathrm{~cm}^{-1}$ spectral range.

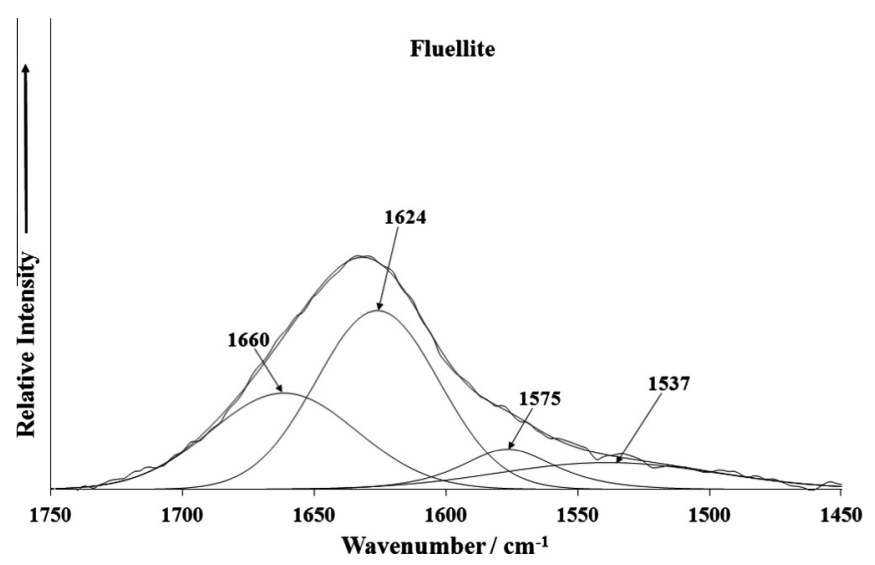

Fig. 3c. Infrared spectrum of fluellite $\mathrm{AU}$ over the $1450-1750 \mathrm{~cm}^{-1}$ range.

Raman bands at 897 and $835 \mathrm{~cm}^{-1}$ (CZ) could be also related to libration modes of water molecules as mentioned.

The infrared spectrum of fluellite in the $850-1300 \mathrm{~cm}^{-1} \mathrm{spec}-$ tral range is shown in Fig. 4c and shows much greater complexity than the Raman spectra. It is noted that the two infrared bands at 920 and $965 \mathrm{~cm}^{-1}$ attributed to the water librational modes show much greater intensity. Weak infrared bands was found at $1026 \mathrm{~cm}^{-1}$, which is attributed to the $v_{1}\left(\mathrm{PO}_{4}\right)$ symmetric stretching vibrations and a strong band at $1061 \mathrm{~cm}^{-1}$ accompanied with

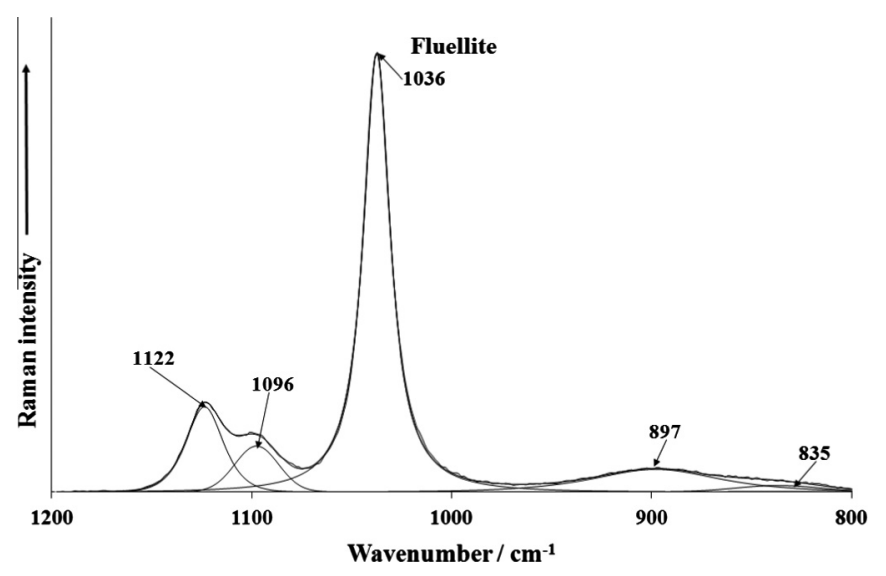

Fig. 4a. Raman spectrum of fluellite $C Z$ over the $800-1200 \mathrm{~cm}^{-1}$ range.

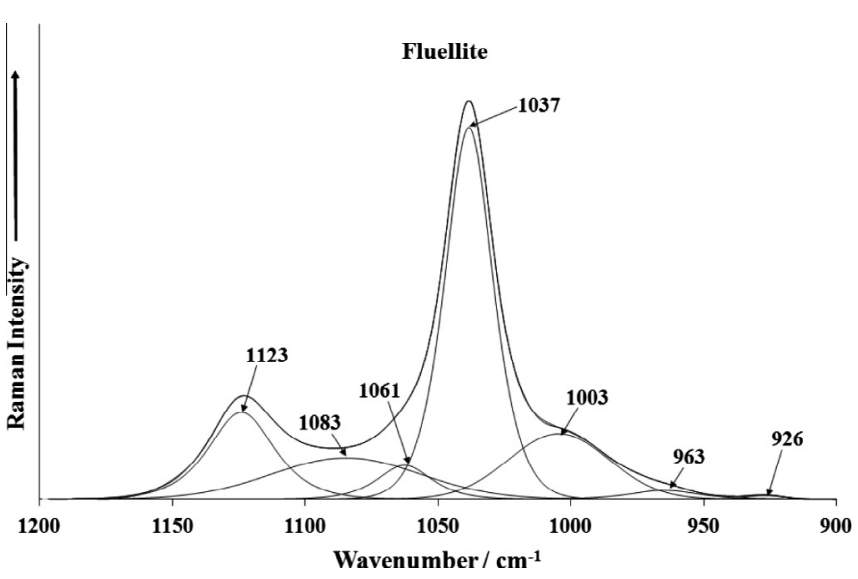

Fig. 4b. Raman spectrum of fluellite AU over the $900-1200 \mathrm{~cm}^{-1}$ range.

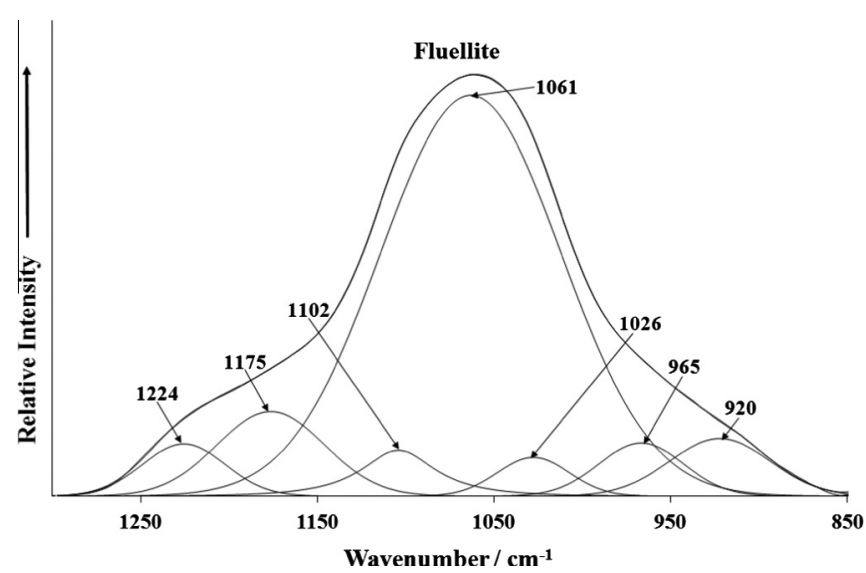

Fig. 4c. Infrared spectrum of fluellite AU over the $850-1300 \mathrm{~cm}^{-1}$ range.

some related weaker bands/shoulders at 1102,1175 and $1224 \mathrm{~cm}^{-1}$ may be assigned to the split triply degenerate $v_{3}$ $\left(\mathrm{PO}_{4}\right)^{3-}$ antisymmetric stretching modes.

The Raman spectra of fluellite in the $350(400)-700 \mathrm{~cm}^{-1}$ spectral range and in the $100-350(400) \mathrm{cm}^{-1}$ spectral range are displayed in Figs. 5a and $5 \mathrm{~b}$ and $6 \mathrm{a}$ and $6 \mathrm{~b}$. Raman bands are observed at 646, 588, 557, 525 and $513 \mathrm{~cm}^{-1}$ (CZ) and 638, 614, 588,522 and $510 \mathrm{~cm}^{-1}$ (AU) [RRUFF $651,585,524 \mathrm{~cm}^{-1}$ ] are assigned to the $v_{4}$ out of the plane bending modes of the $\left(\mathrm{PO}_{4}\right)^{3-}$ 


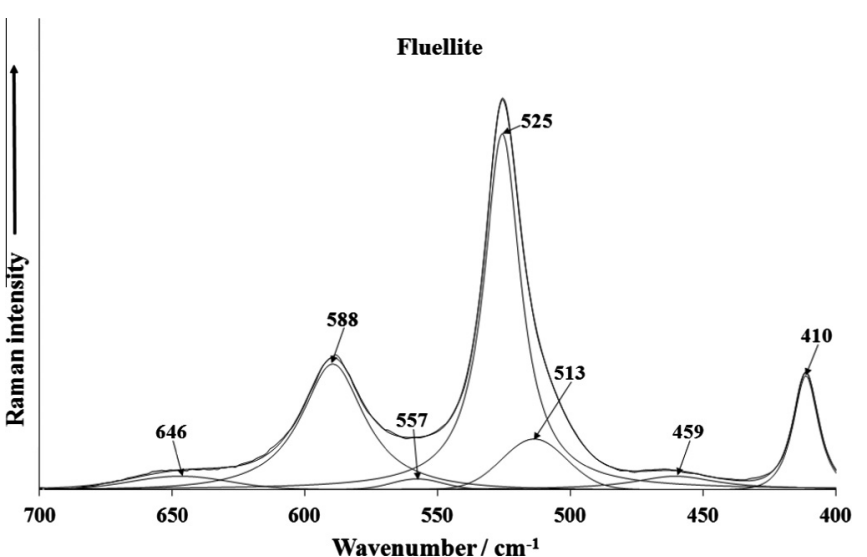

Fig. 5a. Raman spectrum of fluellite $\mathrm{CZ}$ over the $400-700 \mathrm{~cm}^{-1}$ range.

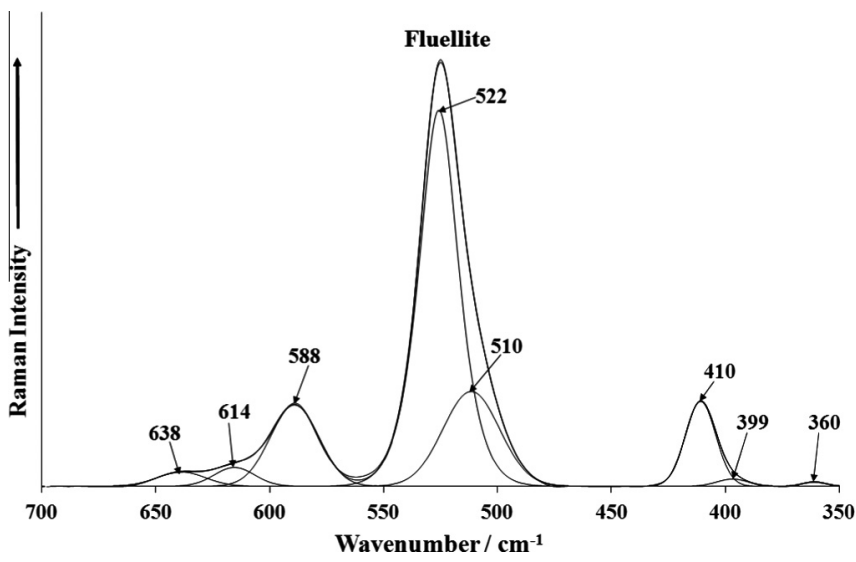

Fig. 5b. Raman spectrum of fluellite AU over the $350-700 \mathrm{~cm}^{-1}$ range.

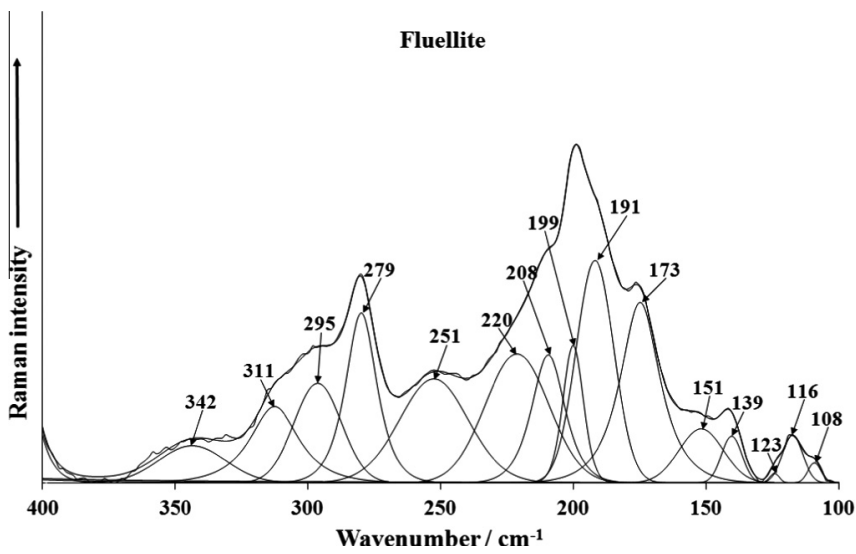

Fig. 6a. Raman spectrum of fluellite $C Z$ over the $100-400 \mathrm{~cm}^{-1}$ range.

units. Some overlap of these bands especially in the range from 585 to $646 \mathrm{~cm}^{-1}$ with the $v \mathrm{Al}(\mathrm{O}, \mathrm{OH}, \mathrm{F})_{6}$ octahedra stretching vibrations may be expected [32]. Raman bands 459 and $410 \mathrm{~cm}^{-1}$ (CZ) and $410 \mathrm{~cm}^{-1}$ (AU) [RRUFF 462 and $406 \mathrm{~cm}^{-1}$ ] are observed. These bands are attributed to the $v_{2}\left(\mathrm{PO}_{4}\right)^{3-}$ bending modes. Raman bands at 342 and $311 \mathrm{~cm}^{-1}$ (CZ) and 399 and $360 \mathrm{~cm}^{-1}$ (AU) [RRUFF $313 \mathrm{~cm}^{-1}$ ] may be assigned to the $v \mathrm{Al}(\mathrm{O}(\mathrm{OH}) \mathrm{F})_{6}$ stretching vibrations. Strong Raman bands are observed at 295, 279 and $251 \mathrm{~cm}^{-1}$ (CZ), 297, 279, 258 and $249 \mathrm{~cm}^{-1}$ (AU) [RRUFF

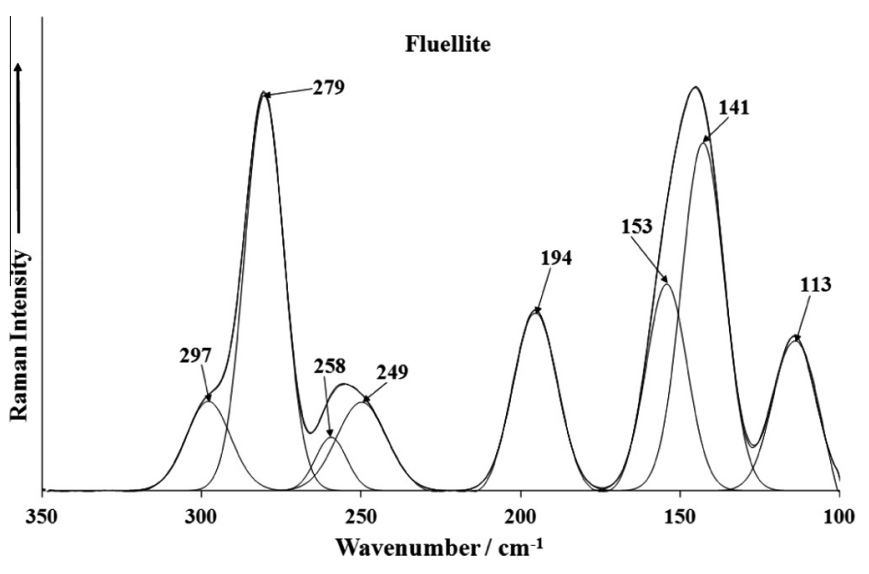

Fig. 6b. Raman spectrum of fluellite AU over the $100-350 \mathrm{~cm}^{-1}$ range.

$276 \mathrm{~cm}^{-1}$ ] are related to the $\mathrm{O}-\mathrm{Al}-\mathrm{O}$ skeletal stretching vibrations. Other Raman bands for fluellite samples studied are observed at $220,208,199,191,173,151,139,123,116,108 \mathrm{~cm}^{-1}(\mathrm{CZ})$ and 194, 153, 141 and $113 \mathrm{~cm}^{-1}$ [RRUFF 211 and $173 \mathrm{~cm}^{-1}$ ]. These bands are described as lattice vibrations.

\section{Conclusions}

1. Raman and infrared spectra of two well defined fluellite samples were recorded.

2. Observed Raman and infrared bands are tentatively interpreted and assigned to the stretching and bending vibrations of $\left(\mathrm{PO}_{4}\right)^{3-}$ tetrahedra and $\left(\mathrm{AlO}_{4} \mathrm{~F}_{2}\right)$ octahedra, and of vibrations of hydrogen bonded water molecules and hydroxyl ions.

3. Approximate $\mathrm{O}-\mathrm{H} \cdots \mathrm{O}$ hydrogen bond lengths are inferred from observed Raman and infrared bands connected with the $v \mathrm{OH}$ stretching vibrations of water molecules and hydroxyl ions.

\section{Acknowledgements}

The financial and infra-structure support of the Queensland University of Technology Inorganic Materials Research Program of the School of Physical and Chemical Sciences is gratefully acknowledged. The Australian Research Council (ARC) is thanked for funding the instrumentation. This work was financially supported by the long-term project DKRVO 2013/02 of the Ministry of Culture of the Czech Republic (National Museum, 00023272). R. Scholz thanks to CNPq - Conselho Nacional de Desenvolvimento Científico e Tecnológico (grants Nos. 306287/2012-9 and 402852/ 2012-5). The downloading of the Raman spectra of fluellite from the RRUFF web site is acknowledged.

\section{Appendix A. Supplementary materials}

Supplementary data associated with this article can be found, in the online version, at http://dx.doi.org/10.1016/j.saa.2014.01.116.

\section{References}

[1] M.A. Cooper, F.C. Hawthorne, A.C. Roberts, E.E. Foord, R.C. Erd, H.T. Evans Jr. M.C. Jensen, Can. Min. 42 (2004) 741-752.

[2] J. Sejkora, R. Škoda, P. Ondruš, P. Beran, C. Süsser, J. Czech Geol. Soc. 51 (2006) $103-147$.

[3] L.E. Kearns, B.S. Martin, Virginia Min. 46 (2000) 9-16.

[4] H.D. Gay, R. Lira, Revista Asoc. Argen. Min. (1987) 27-32.

[5] K. Tazaki, W.S. Fyfe, C.B. Dissanayake, Appl. Geochem. 1 (1986) 287-300.

[6] K. Tazaki, W.S. Fyfe, C.B. Dissanayake, Chem. Geol. 60 (1987) 151-162.

[7] A.M. Fransolet, J. Jedwab, R. Van Tassel, Ann. Soc. Geol. Belg. 97 (1974) 27-38. 
[8] W.A. Henderson Jr., V. Peisley, Min. Rec. 16 (1985) 477-480.

[9] S. Menchetti, C. Sabelli, N. Jb, Miner. Mh. 1981 (1981) 505-510.

[10] M.C. Jensen, J.C. Rota, E.E. Foord, Min. Rec. 26 (1995) 449-469.

[11] V.Y. Karpenko, L.A. Pautov, A.A. Agakhanov, Zap. Ross. Min. Obsh. 138 (2009) $83-90$.

[12] A. Levy, Annals Phil. 8 (1824) 241-245.

[13] P. Groth, Jahrb. f Min. 2 (1883) 324-327.

[14] H. Laubmann, H. Steinmetz, Zeit. Krist. 55 (1920) 549-557.

[15] A. Scholz, H. Strunz, Geol. Pal. 1940A (1940) 133-137.

[16] B.B. Guy, G.A. Jeffrey, Amer. Min. 51 (1966) 1579-1592.

[17] B.B. Guy, G.A. Jeffrey, R. Van Tassel, Amer. Min. 52 (1967) 1577.

[18] J. Sejkora, T. Rídkošil, V. Šrein, N. Jb. Miner. Abh. 175 (1999) 105-124.

[19] J. Sejkora, F.C. Hawthorne, M.A. Cooper, J.D. Grice, J. Vajdak, J.L. Jambor, Can. Min. 47 (2009) 159-164.

[20] J. Sejkora, K. Babka, R. Pavlíček, Bull. Mineral.-Petrolog. Odd. Nár. Muz. (Praha) 20 (2012) 208-212.

[21] J. Sejkora, P. Pauliš, P. Rus, R. Škoda, L. Koťátko, Bull. Mineral.-Petrolog. Odd. Nár. Muz. (Praha) 20 (2012) 177-182.

[22] R.L. Frost, J. Cejka, J. Sejkora, D. Ozdín, S. Bahfenne, E.C. Keeffe, J. Raman Spectrosc. 40 (2009) 1907-1910.
[23] J. Čejka, R.L. Frost, J. Sejkora, E.C. Keefee, J. Raman Spectrosc. 40 (2009) 1464 1468.

[24] R.L. Frost, J. Sejkora, J. Čejka, E.C. Keeffe, J. Raman Spectrosc. 40 (2009) 15461550.

[25] J. Sejkora, J. Litochleb, J. Čejka, P. Černý, Bull. Mineral.-Petrolog. Odd. Nár. Muz. (Praha) 21 (2013) 37-46.

[26] E.S. Pilkington, E.R. Segnit, J.A. Watts, Min. Mag. 46 (1982) 449-452.

[27] P. Ondruš, ZDS - software for analysis of X-ray powder diffraction patterns. Version 6.01. Useŕs guide (1995), Praha.

[28] C.W. Burnham, Yearb. 61 (1962) 132-135.

[29] K. Nakamoto, Infrared and Raman Spectra of Inorganand Coordination Compounds, J. Wiley and Sons, New York, 1986.

[30] V.V. Pechkovskii, R.Ya. Mel'nikova, E.D. Dzyuba, T.I. Baranikova, M.V. Nikanovich, Nauka Moscow, 1981 (in Russian).

[31] A. Rahten, P. Benkich, A. Jesih, Acta Chim. Slov. 46 (1999) 339-354.

[32] D.K. Breitinger, H.H. Belz, L. Hajba, V. Komlosi, J. Mink, G. Brehm, D. Colognesi, S.F. Parker, R.G. Schwab, J. Mol. Struct. 706 (2004) 95-99.

[33] M. Diafi, M. Omari, Boletin de la Sociedad Española de Cerámica y Vidrio 51 (2012) 337-342.

[34] E. Libowitzky, Monatshefte für Chem. 130 (1999) 1047-1059. 